\title{
Interannual Fluctuations of the Tropical Monsoon Circulation Over the Greater WMONEX Area
}

\author{
By Minoru Tanaka \\ Institute of Geoscience, University of Tsukuba, Ibaraki 305, Japan \\ (Manuscript received 27 July 1981, in revised form 21 September 1981)
}

\begin{abstract}
Synoptic analyses were conducted of interannual variations of the tropical winter monsoon circulation during the 20-year period from 1961 to 1980 . The $150 \mathrm{mb}$ easterly wind at Singapore was used as an indicater of the strength of the tropical winter monsoon over the WMONEX area (South China Sea-Indonesia-northern Australia). Evidence has been shown that interannual fluctuations of the winter monsoon are deeply associated with the corresponding changes in the Walker circulation.

The monsoon was found to be strong when the sea level pressure was high near Tahiti and low near the Cocos Islands. The monsoon was weak when the opposite conditions were observed. The 1978-79 MONEX winter was one with a weak monsoon. There is a strong tendency for the formation of two ITCZs when the monsoon is strong. In comparison, only one ITCZ near New Guinea is observed during weak monsoon years.
\end{abstract}

\section{Introduction}

The MONEX area (South China Sea-Indonesianorthern Australia) is characterized by prominent monsoon circulations during the northern winter. Recently, a series of research work on the interannual fluctuations of the tropical winter monsoon was conducted. Ramage (1968) analyzed the winter monsoon circulation and associated precipitation during January 1963 and January 1964. He suggested that a strong easterly wind at the $200 \mathrm{mb}$ level near Singapore was associated with the strong winter monsoon at the low level. Krishnamurti et al. (1973) confirmed the existence of a divergent circulation at the $200 \mathrm{mb}$ level over the Indonesian region in the 1969 northern winter. Murakami and Unninayar (1977) and Murakami (1978) utilized the wind data at the $200 \mathrm{mb}$ level for the 1970-71, 1971-72, and 197273 northern winters and computed the divergence field of the tropical atmosphere. They showed that the ascending motion over the Indonesian region is a climatological feature. Finally, Murakami (1979a, 1979b) investigated the detailed structure of winter monsoon surges in the East and South China Seas.

In the current study, interannual fluctuations of the tropical winter monsoon were analyzed for a 20-year period from 1961 to 1980 . The relationship between the changes in winter monsoons (including ITCZ) and the distribution of the precipitation was also investigated. The relationship to the Walker circulation was also analyzed.

\section{Data and methods of synoptic investigation}

The primary source of data was Monthly Climatic Data for the World published by the NOAA in the USA. The upper air data for the People's Republic of China was obtained from the Daily Weather Map published by the Japan Meteorological Agency. In the current study, the data for December to February, covering the area shown in Figure 1 are used from above sources. The precipitation data for Indonesia were not available for a period from 1965 to 1975 .

In every year of the research period, the monthly mean maps of the total precipitation, the circulation at the $850 \mathrm{mb}$ and $150 \mathrm{mb}$ level are drawn. The circulation at the $150 \mathrm{mb}$ level shows the maximum intensity of the easterly wind near Singapore which represents the upper return flow of the Hadley circulation associated with the monsoon circulation.

Fig. 1 shows the mean zonal wind at the 150 $\mathrm{mb}$ level in winter (December-February). The easterly wind observed near the equator has a 


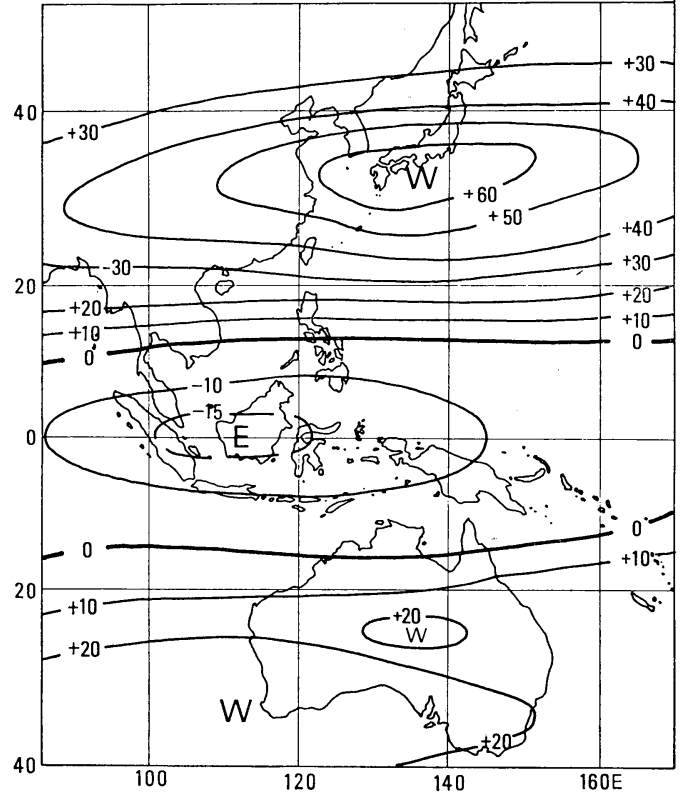

Fig. 1 Mean zonal wind at the $150 \mathrm{mb}$ level in winter (December to February) (unit: $\mathrm{ms}^{-1}$ ).

maximum speed of $15 \mathrm{~ms}^{-1}$ near Singapore. The meridional wind at the $150 \mathrm{mb}$ level (not shown) is southerly over the Indochina Peninsula and northerly over Cocos Island located to the south of Java. It appears that the meridional wind is strong when the easterly wind at the $150 \mathrm{mb}$ level at Singapore is strong. In this study, the yearto-year fluctuations of the $150 \mathrm{mb}$ zonal wind measured at Singapore is used as an indicator of the changes in strength of the tropical winter monsoon. At this level, there are few orographic distortion of the wind. Hence this wind is a good measure of the Hadley circulation.

\section{Interannual changes in precipitation}

An inspection of the $150 \mathrm{mb}$ zonal wind at Singapore during December to February in the study (January 1961 to February 1980) reveals that the interannual fluctuations of the zonal wind were the largest in January with a standard deviation of $7.7 \mathrm{~ms}^{-1}$. In December and February these standard deviations were $5.0 \mathrm{~ms}^{-1}$ and $5.5 \mathrm{~ms}^{-1}$, respectively.

For this reason, this study is emphasized on January. With a notable exception of 1978, every January which observed strong easterly winds $\left(>18 \mathrm{~ms}^{-1}\right)$ experienced strong easterly winds for the entire winter. It was shown that the MONEX winter monsoon was stronger than only

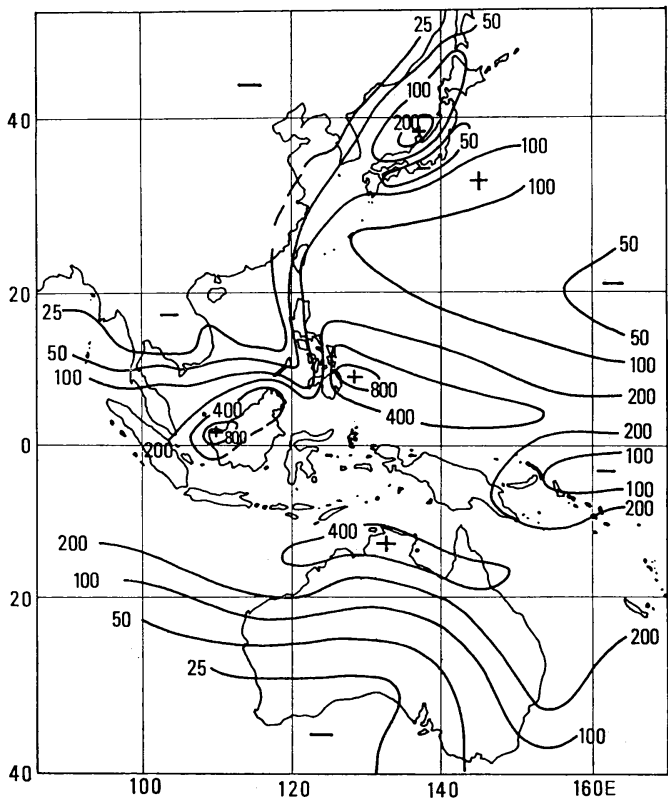

Fig. 2a Composite map of the precipitation in 6 January with strong $150 \mathrm{mb}$ easterly wind over Singapore. (unit: $\mathrm{mm}$ )

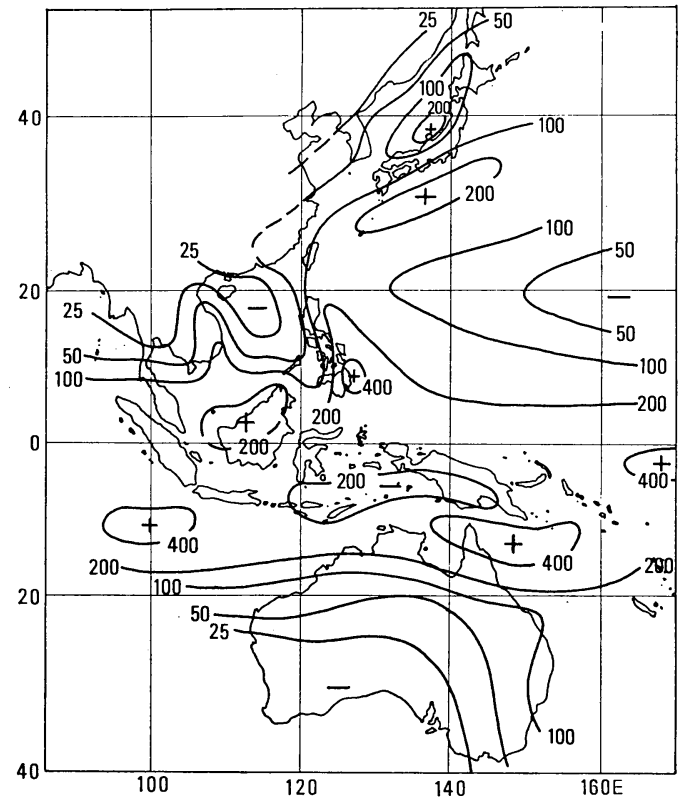

Fig. 2b Composite map of the precipitation in 6 January with weak $150 \mathrm{mb}$ wind over Singapore. (unit: $\mathrm{mm}$ )

3 of the past 20 winter monsoons.

The relationship between the fluctuations of the $150 \mathrm{mb}$ zonal wind at Singapore and the lowlevel winter monsoon was investigated by constructing composite maps. An inspection of the 


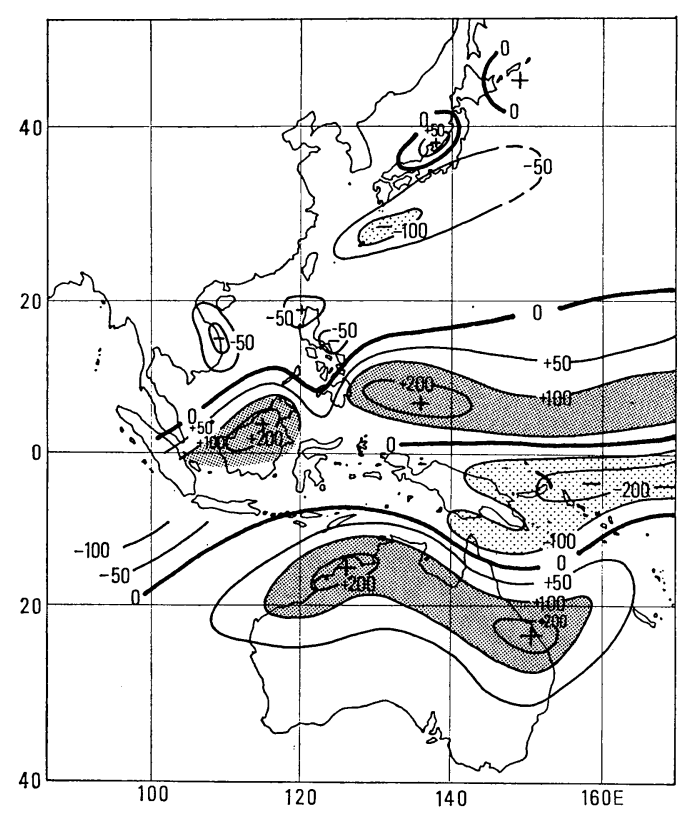

Fig. 3 Difference in the precipitation in January. Positive values indicates increase in the precipitation when the easterly wind is strong. (unit: $\mathrm{mm}$ )

monthly total precipitation indicates that every January with the easterly wind over $20 \mathrm{~ms}^{-1}$ (except 1967) tends to form two ITCZs.

Fig. 2a depicts a composite map of the precipitation in January of 1962, 1963, 1968, 1971, 1974 and 1975 (when a strong easterly wind at $150 \mathrm{mb}$ was observed over Singapore). North Borneo, eastern Mindanao and Micronesia, located in the northern ITCZ, are heavy precipitation regions. The southern ITCZ is encountered over northern Australia. On the other hand, the regions to the east of New Guinea are dry with less than $100 \mathrm{~mm}$ of precipitation.

A similar composite map (Fig. 2b) for January of 1964, 1965, 1966, 1969, 1970 and 1972 (with a weak $150 \mathrm{mb}$ easterly wind of less than $10 \mathrm{~ms}^{-1}$ at Singapore), shows increased (decreased) rainfall over the equatorial western South Pacific (western North Pacific, Borneo and northern Australia). The difference in the two composite maps was obtained by subtracting the Fig. $2 b$ from Fig. 2a. This is shown in Fig. 3.

Two zones of increased precipitation (over $100 \mathrm{~mm}$ ) nearly coincide with the two ITCZs observed during January of strong $150 \mathrm{mb}$ easterly winds. The recent data (1976-1981) from Indonesia suggests that the two ITCZs are well defined to the east of $130^{\circ} \mathrm{E}$ in January. The decrease in the precipitation during these years of strong monsoon circulation is substantial to the east of New Guinea and in the polar front zones to the south of Japan.

\section{Interannual changes in the winter monsoon circulations}

Similar comparison between the strong easterly case and the weak easterly case were made for the $500 \mathrm{mb}$ dewpoint depression, the $850 \mathrm{mb}$ geopotential height and the surface temperature. Fig. 4 reflects the changes in dewpoint depression. The pattern of two ITCZs, and the increased subsidence in the subtropical high near Taiwan and a dry zone near New Guinea is the main feature of the strong monsoon regime.

Fig. 5 shows the circulation at $850 \mathrm{mb}$. There are three areas of decreased geopotential height (increased cyclonic circulation) when the $150 \mathrm{mb}$ easterly wind over Singapore is strong. At this time, the equatorial westerlies in Indonesia, the cold monsoon surge from Siberia in the East China Sea and southern Japan, the northeast monsoon in the South China Sea are strong. Thus January with a strong easterly wind at $150 \mathrm{mb}$ corresponds to the case of a strong monsoon (Hadley) circulation at the low level.

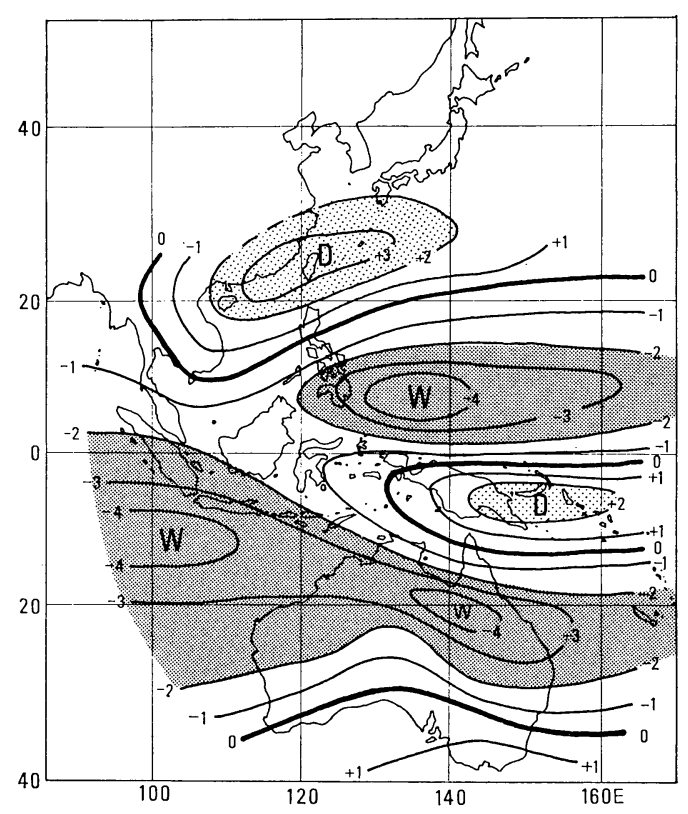

Fig. 4 Difference in the $500 \mathrm{mb}$ dewpoint depression in January. Negative values indicate increases in the moisture content of the atmosphere when the easterly wind is strong. (unit: ${ }^{\circ} \mathrm{C}$ ) 


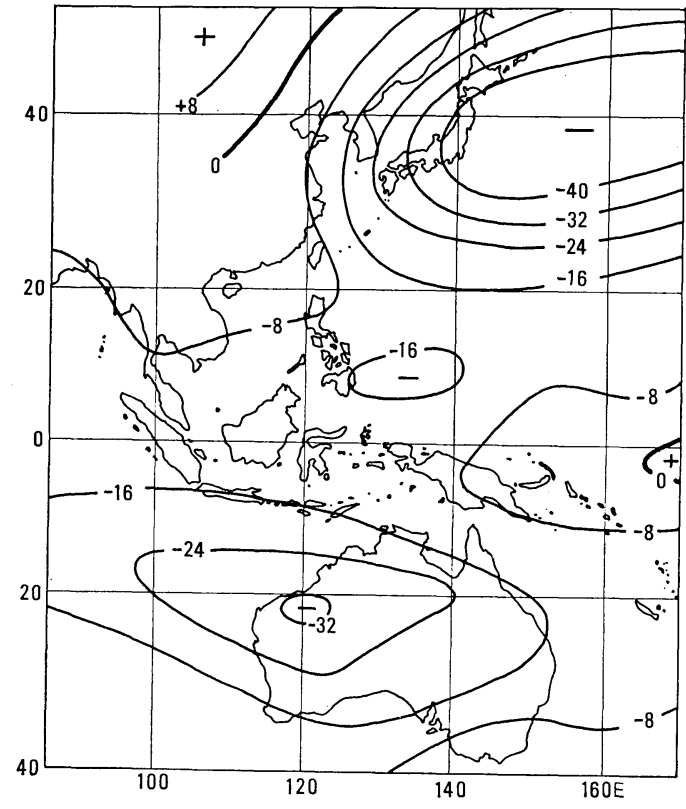

Fig. 5 Difference in the $850 \mathrm{mb}$ geoptential height in January. Negative values indicate decreases in the geopotential height when the easterly wind is strong. (unit: geopotential meters)

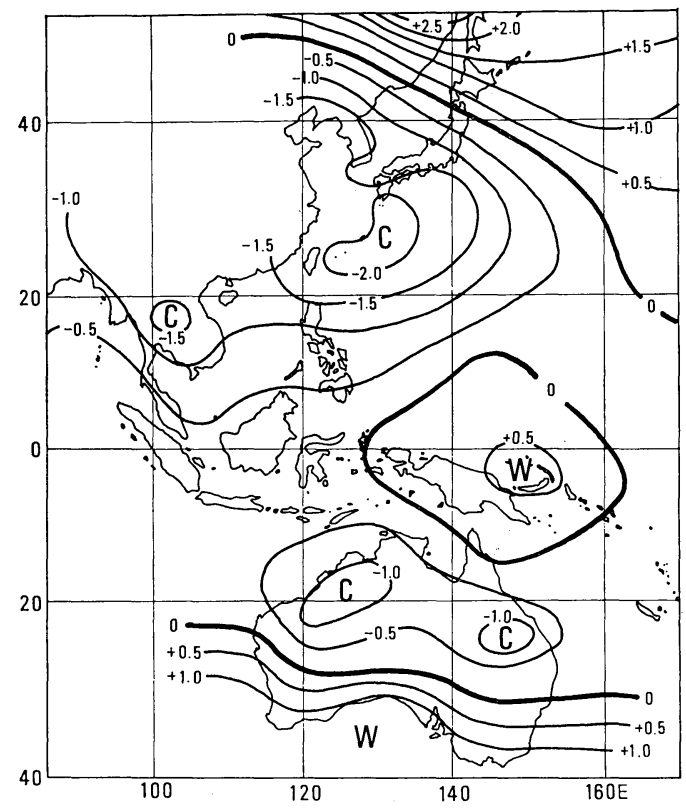

Fig. 6 Difference in the surface temperature in January. Negative values indicate low temperature when the easterly wind is strong. (unit: ${ }^{\circ} \mathrm{C}$ )
Fig. 6 shows the difference in the surface temperature. The frequent cold surges in the East and South China Seas are shown by decreased temperature for January of a strong monsoon. The increase in the cloudiness associated with heavy rain in northern Australia is responsible for a drop in the surface temperature there. The higher temperature near New Guinea reflects with decreased cloudiness.

A similar survey of the winter monsoon was also conducted for December and February. In general, the results are similar to those of January. A notable exception is the westward extension of the northern ITCZ to the east coast of the Malay peninsula in December. Hence, heavy precipitation tends to occur in the eastern Malay peninsula when the winter monsoon is strong in December.

\section{Relationship to the Walker circulation}

The Walker circulation was discovered by Walker and Bliss $(1932,1937)$ and subsequently became recognized as an important mode of fluctuations of the tropical atmosphere. During the northern winter, the center of action lies over the South Pacific Ocean and Australian regions. The climatological elements such as the sea level pressure are negatively correlated between these two regions. Recently, Quinn (1974), Kidson (1975), and Wyrtki $(1975,1977)$ investigated the relationship between the Walker circulation and El Nino.

To investigate the relationship between the Walker circulation and the winter monsoon, the 5 month averages of the sea level pressure from November to March at Cocos Island (Indian Ocean), Darwin, Tahiti and Easter Islands were investigated. Because of the seasonal change of the center of action, the pressure at Cocos and Tahiti was found to show the highest negative correlation $(R=-0.76)$ for 18 winters from 1961 to 1978 .

Using the data from these two stations, the Walker Circulation Index (W.C.I.) was defined by the following method: For each of the two stations, the departures from the normal sea level pressure were obtained. These departures were then normalized by the standard deviation of the data. Finally W.C.I. is obtained by the following formula:

$$
\text { W.C.I. }=\frac{P(1)-P(2)}{|P(1)+P(2)|+1}
$$

where 


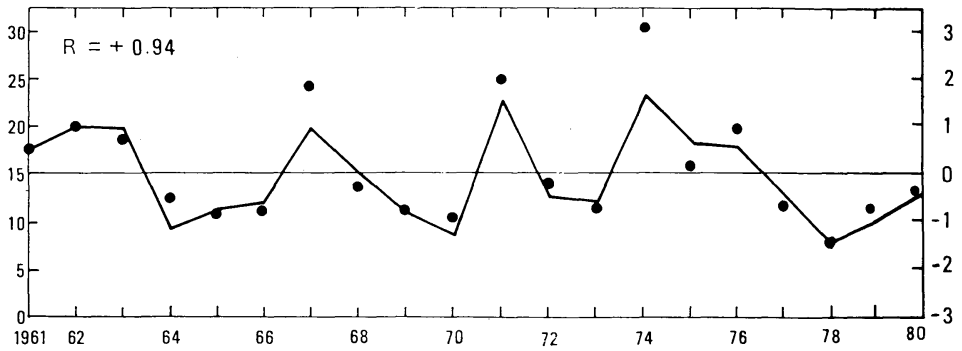

Fig. 7 Fluctuations of the winter monsoon (solid line) and the Walker Circulation Index (large black dot). The scale on the left is the 3-month average of the $150 \mathrm{mb}$ wind speed over Singapore in $\mathrm{ms}^{-1}$. The scale on the right is the Walker Circulation Index.

$P(1)=$ normalized departures of the 5 month average, sea-level pressure at Tahiti.

$\mathrm{P}(2)=$ The corresponding departures at the Cocos Island.

This W.C.I. is defined to have a positive value when the pressure is high at Tahiti (South Pacific). Since the Walker circulation has a long period of oscillation, the 3 month average from December to February of the winter monsoon (expressed by the $150 \mathrm{mb}$ zonal wind at Singapore) was used. Fig. 7 shows the fluctuations of the Winter monsoon and W.C.I. In the 20 winters from 1961 to 1980 , the correlation between these fluctuations is +0.94 . This shows that the interannual fluctuations of the winter monsoon are part of the corresponding fluctuations in the Walker circulation. In the WMONEX winter of 1978-79, weak monsoon and negative W.C.I. were observed.

The synoptic patterns of this oscillation were then investigated. Fig. 8a shows the mean sea level pressure in January over the Pacific Ocean region. It reveals the existence of the Southern Hemisphere trough extending from the eastern Indian Ocean $\left(15^{\circ}-20^{\circ} \mathrm{E}\right)$ to the western South Pacific $\left(10^{\circ} \mathrm{S}, 160^{\circ} \mathrm{W}\right)$.

Fig. $8 \mathrm{~b}$ shows the difference in the sea level pressure between the winters with strong easterly wind of over $19.9 \mathrm{~ms}^{-1}$ at the $150 \mathrm{mb}$ level $(1962,1963,1971,1974)$ and the winters with weak easterly wind of less than $10.7 \mathrm{~ms}^{-1}$ (1964, 1969, 1970, 1978). In winters with strong monsoon circulation, the equatorial trough is predominant to the south of Java and northern

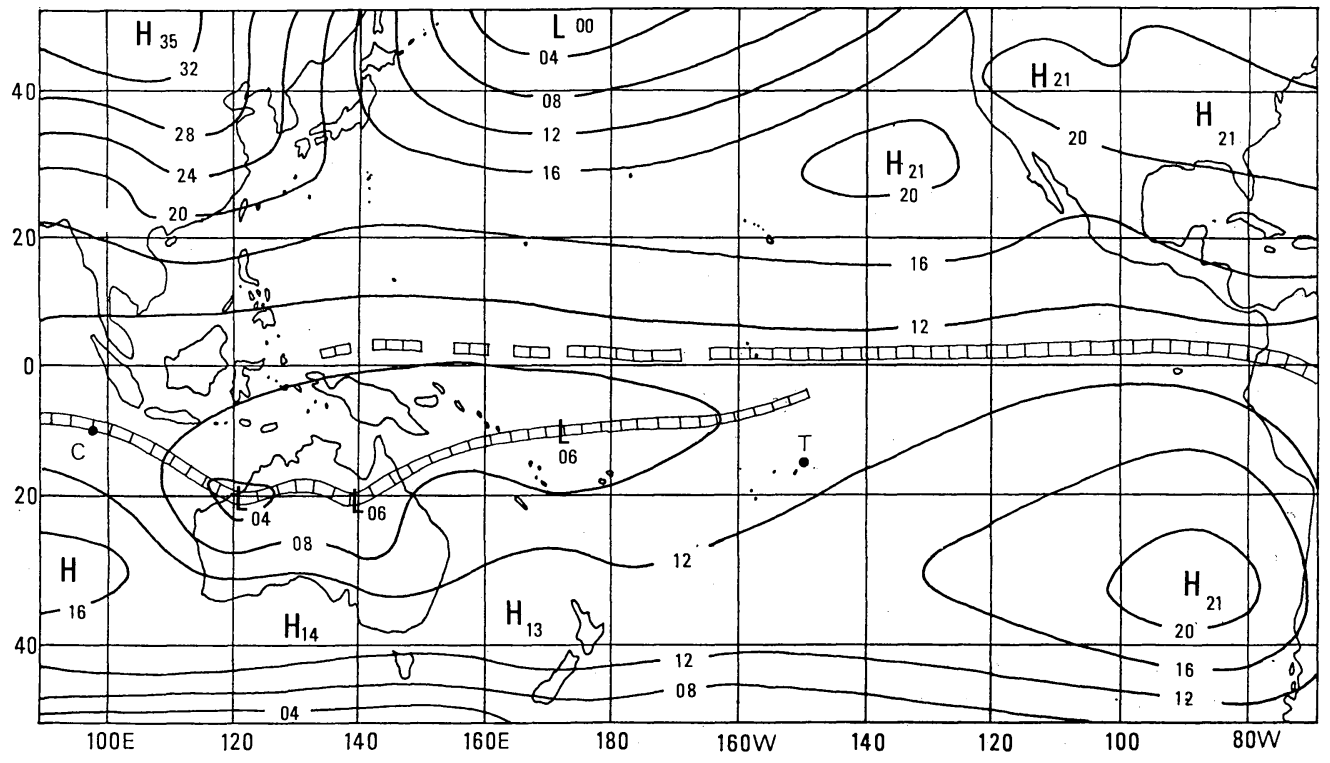

Fig. 8a Mean sea level pressure in January. (unit: 1,000 mb) C: Cocos Island, T: Tahiti 


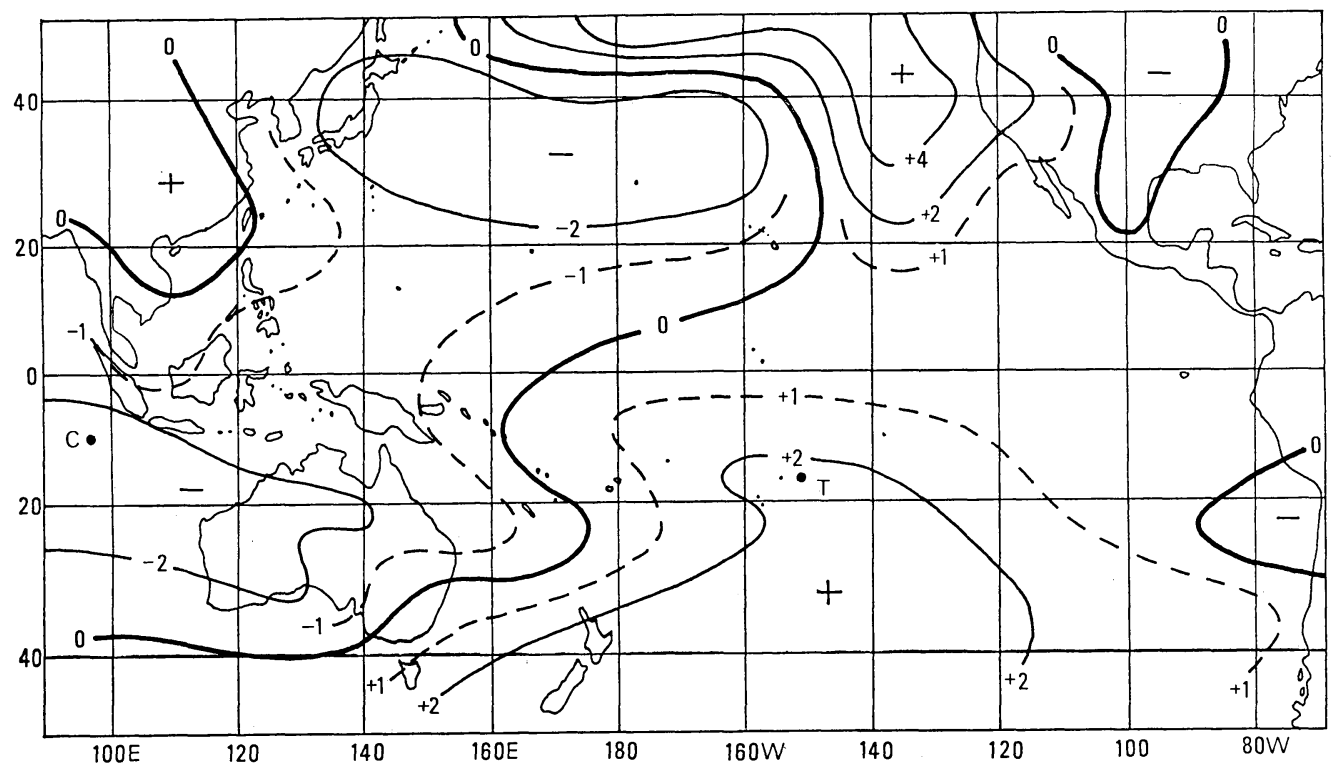

Fig. $8 \mathrm{~b}$ Difference in the sea level pressure in January. Negative values indicate decreases in the sea level pressure when the easterly wind is strong. (unit: mb)

Australia, with strong tradewinds and cold sea surface temperature to the north of Tahiti. The active zone of ITCZ shifts toward Indian Ocean. The northeast tradewinds near the date line are weak.

In the higher northern latitudes, the Aleutian low is displaced southwest toward Japan and slightly weaker than normal. The correlation of the central pressure of this low to the $150 \mathrm{mb}$ wind at Singapore is only +0.39 in 18 winters from 1961 to 1978 . The intensity of the Siberian high also has a similar low correlation $(+0.29)$. Thus, the influence of the circulation at the middle latitudes appears to be insignificant when compared to the Walker circulation.

\section{Conclusion}

This study indicates a strong association of the interannual fluctuations of the winter monsoon with the Walker circulation. When the sea level pressure is high near Tahiti, it is low to the south of Java. In these winters, the active zone of ITCZ shifts toward the Indian Ocean and the winter monsoon near Singapore was found to be strong.

When the winter monsoon is strong, there is a tendency for the formation of two ITCZs with heavy precipitation over the South China SeaIndonesia region. In contrast, only one ITCZ near New Guinea is observed when the monsoon is weak. In the WMONEX winter of 1978-79, the monsoon was weak and only one ITCZ near $5^{\circ} \mathrm{S}$ was observed. Only 3 of the past 20 winters had weaker monsoon (1964, 1970, and 1978) compared to the MONEX winter.

\section{Acknowledgements}

The author is grateful to Dr. Masatoshi M. Yoshino of the Institute of Geoscience for many helpful suggestions and encouragements. In addition, the author is deeply indebted to $\mathrm{Mr}$. M. Sato for drawing the figures. Thanks are also due to Dr. Takeshi Kawamura and the other members of the Institute for many helpful suggestions. This paper is an extension of the doctor thesis conducted at the University of Tsukuba.

\section{References}

Kidson, J. W., 1975: Tropical eigenvector analysis and the Southern Oscillation. Mon. Wea. Rev., 103, 187-196.

Krishnamurti, T. N., M. Kanamitsu, W. J. Koss, and J. O. Lee, 1973: Tropical east-west circulation during the northern winter. J. Atmos. Sci., 30, 780-787.

Murakami, T., and M.S. Unninayar, 1977: Atmospheric circulation during December 1970 through February 1971. Mon. Wea. Rev., 105, 1024-1038.

Murakami, T., 1978: Winter circulations and wavenumber domain energetics at $200 \mathrm{mb}$. J. Meteor. Soc. Japan, 56, 215-231.

1979a: Winter monsoonal surges over East and Southeast Asia. J. Meteor. Soc. Japan, 57, 133-158. 
1979b: Structure of winter monsoon surges over the Far East obtained from empirical orthogonal function analysis. J. Meteor. Soc. Japan, 57, 386-398.

Quinn, W. H., 1974: Monitoring and predicting El Nino invasions. J. Appl. Meteor., 13, 825-830.

Ramage, C. S., 1968: Role of a tropical "Maritime continent" in the atmospheric general circulation. Mon. Wea. Rev., 96, 365-370.
Walker, G. T., and E. W. Bliss, 1932: World Weather, V. Mem. of the Roy. Meteor. Soc., IV, 53-80. 1937: World Weather, VI. Mem. of the Roy. Meteor. Soc., IV, 119-139.

Wyrtki, K., 1975: El Nino-the dynamic response of the equatorial Pacific Ocean to atmospheric forcing. J. Phys. Oceanogr., 5, 572-584.

1977: Sea level during the 1972 El Nino. J. Phys. Oceanogr., 7, 779-787.

\section{冬の MONEX 地域における熱帯モンスーンの年々変動}

\section{田 中 実 \\ 筑波大学地球科学系}

MONEX 地域に特いて冬季モンスーンを1961年から 1980年までの20年間について年々の変動を総観的に解析 した。冬季モンスーンは熱帯大気の主変動である Walker Circuration によって変動していることが分かった。 シンガポール上空 $150 \mathrm{mb}$ 面で観測される東風が強い冬は, 冬季モンスーンが活発で南太平洋の海面気王が高く ジャワ島の南方の気圧が低い。またこのような冬は ITCZ が二本でき易い。冬季モンスーンが弱い年はITCZ はニューギニア付近で一本にまとまる。MONEX 年の冬もモンスーンが弱い冬であった。 